\title{
Assessment of the risk of soil erosion using RUSLE method and SWAT model at the M'dez Watershed, Middle Atlas, Morocco.
}

\author{
M'hamed BOUFALA ${ }^{1,2 *}$, Abdellah EL HMAIDI ${ }^{1}$, Khalid $\mathrm{CHADLI}^{3}$, Ali ESSAHLAOUI ${ }^{1}$, Abdelhadi EL OUALI ${ }^{1}$ and \\ Abdelhakim LAHJOUJ ${ }^{1}$
}

\author{
${ }^{1}$ Water Science and Environmental Engineering Team, Laboratory of Geoengineering and Environment, Department of Geology, Facul ty \\ of Sciences, Moulay Ismail University, BP 11201, Zitoune Meknes, Morocco. \\ ${ }^{2}$ National Office of Electricity and Drinking Water -Water Branch-, Meknes, Moroco. \\ ${ }^{3}$ Department of Geography, Faculty of Letters and Human Sciences, Moulay Ismail University. B.P. 11202, Zitoune, Meknes, Morocco.
}

\begin{abstract}
The preservation of soil resources is a primary global concern and a permanent challenge for all Mediterranean countries. In Morocco, the capacity of dam reservoirs continues to decline from one year to the next due to the rate of siltation, mainly due to the phenomenon of water erosion. Indeed, the origins of this erosion are generally related to land use planning, deforestation, agricultural practices and low vegetation cover. However, it is imperative to quantify soil erosion and its spatial distribution to achieve sustainable land use and governance of this resource. The SWAT hydro-agricultural model and the integrated RUSLE model were used to assess soil losses and characterize the degraded areas of the M'dez watershed, located in the upper Sebou, north of the Middle Atlas, and extend on an area of $3350 \mathrm{~km}^{2}$. The results obtained during this work show that the average soil losses estimated by the two models are consistent. For the SWAT model, the specific degradation of the watershed is estimated at $3.95 \mathrm{t} /$ ha / year, whereas for the RUSLE model, the average loss of the basin is estimated at $2.94 \mathrm{t} /$ ha / year). However, the use of these two models (SWAT and RUSLE), for the assessment and characterization of degraded areas at the level of Moroccan watersheds, has become a much sought-after approach for good soil conservation management.
\end{abstract}

\section{INTRODUCTION}

The storage capacity lost due to the siltation of dam reservoirs is estimated at 75 million $\mathrm{m}^{3} /$ year, which is equivalent to the loss of an average dam every two years [1]. This situation may be further accentuated by the increased degradation of soils and vegetation cover, which will lead to the erosion aggravation [2]. Water that fails to infiltrate and sinks to the soil surface is the agent of water erosion soil and transport of soluble soil components, including contaminants [3]. It results from the detachment, under the effect of the kinetic energy of the drops of rain and the transport of particles of the soil of their original site by water, degrading the quality of water and the fertility of the soil and reducing the capacity of the dams [4]. The Mediterranean Basin is a very significant region that has been settled since the Pre-Historicera [5]. The current and future context of the Mediterranean requires studies to limit the harmful effects of soil erosion risks. Overall, there are substantial differences in the status and trend of soil erosion in different regions. Many parts of Europe, North America, and the Pacific Southwest generally show a tendency towards improvement, although this follows from many decades of soil loss due to significant erosion associated with expansion agricultural. Sub-Saharan Africa has a variable tendency towards erosion, so that Asia, Latin America and the Caribbean, the Near East and North Africa have adverse or awful erosion conditions and a tendency to deterioration. In the latter region, wind erosion is the leading cause of deplorable conditions soil and the propensity to the decline [3]. The emergence of remote sensing and geographic information systems (GIS) technologies is a significant solution for solving both the problem of data access and the implementation of spatialized models. Space-based remote sensing offers new horizons for the collection of spatial data and the

Corresponding author: simoboufala@gmail.com 
measurement of model parameters, so that researchers believe that the significant evolution of watershed modeling in the future will be the result of the development data collection by satellites [6]. Our contribution to the prospects of Moroccan watershed development for the reduction of the negative impacts of the phenomenon of erosion consists of applying two different methods; the universal soil loss equation RUSLE-GIS. And the SWAT model coupled with ArcGIS. RUSLE is a comprehensive, practical and straightforward approach to estimate soil erosion [7] whiles the SWAT model requires almost the same data, and it is also frequently used for erosion studies [8].

\section{STUDY AREA}

Geographically the M'dez watershed with a total area of $3350 \mathrm{Km}^{2}$ and a perimeter of about $378 \mathrm{~km}$, is part of the extensive basin Sebou located in northern Morocco, entirely in the Middle Atlas Mountains. It is situated between the meridians $515000 \mathrm{~m}$ and $625000 \mathrm{~m}$, and between the parallels $345000 \mathrm{~m}$ and $270000 \mathrm{~m}$. It depends on the region of Fez-Meknes and spreads over the provinces of Boulemane, Sefrou, and Ifrane and concern four circles (Sefrou, El Menzel, Boulemane, Ifrane) and 19 rural municipalities (Fig. 1). The M'dez watersched is exposed to humid westerly dominant flows, whose altitudes exceed $2000 \mathrm{~m}$. The geological outcrops encountered are from Mesozoic to Cenozoic ages. The water of the watershed is coming from the Middle Atlas flows in predominantly limestone sedimentary formations of the Lias. This unit has been the subject of repeated faults and tectonic accidents over time which, in addition to its calcareous nature, predestined it for the actions of erosion, especially to meteoric waters charged with carbon dioxide. This resulted in a series of circulations by the wells or diaclasses which can go up to the creation of true channels and caves. The thickness of these limestone formations can reach $300 \mathrm{~m}$. The filtered waters reappear in the form of sources or feed groundwater or artesian or underflow of the valley [9] laterally.

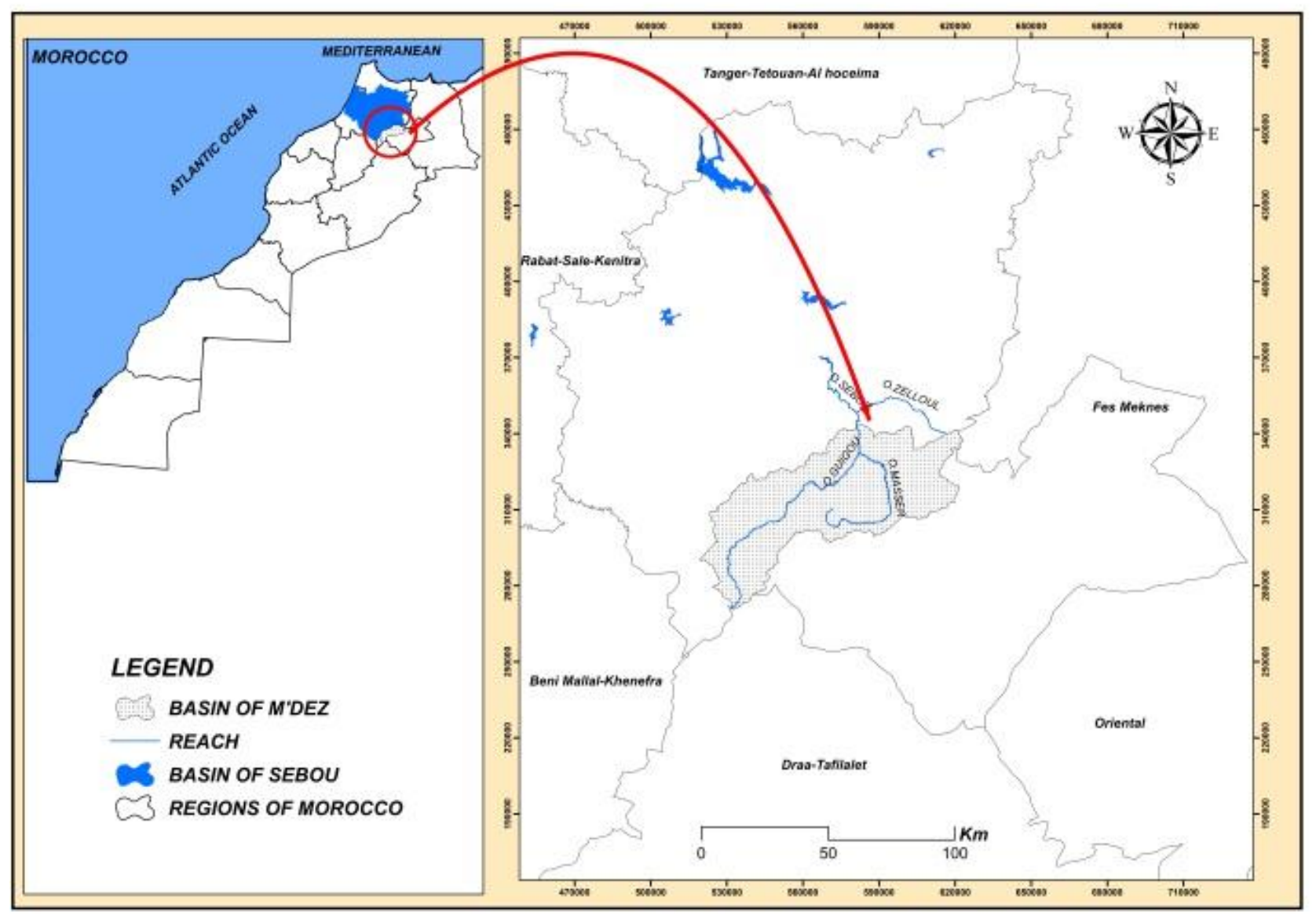

Fig. 1 : Geographic location of the study area of M'dez watersched. 


\section{MATERIALS AND METHODS}

\subsection{SWAT MODEL}

In our study, the first method was used to estimate erosion Risk is the Soil and Water Assessment Tool (SWAT). The SWAT has been developed to predict the impact of land management practices on water, sediments and agricultural chemical yields in large complex watersheds with varying soils, land use and management conditions [10-11]. Texas A\&M University has developed a graphical and visual interface of SWAT, ArcSWAT, that uses the digital elevation model (DEM), coordinates of climate and gauging stations, hydrographic network and ground cover in grid or polygon, as inputs to the model. Besides, it facilitates the extraction of input parameters and visualizes the results [12]. Application of SWAT to assess hydrology and sediment in the horn of Africa is well documented [13-14].SWAT is found to be a favourable model for continuous and long-term simulations of all major components (chemical, sediment and hydrology) in agriculture-dominated basins [15]. The model applies to semi-arid and similar environments where limited number of gauge stations is found [16]. The study area is divided into watersheds based on the DEM, and these watersheds are further divided into hydrologic response units (HRU) that consist of unique combinations of soils, land-uses and slope categories [11]. Simulation of the terrestrial phase, according to a daily time step, is based on the following water balance (Eq. 1):

$\mathrm{SWt}=\mathrm{SW} 0+\sum_{\mathrm{i}=1}^{\mathrm{t}}\left(\mathrm{R}_{\text {day }}-\mathrm{Q}_{\text {surf }}-\mathrm{E}_{\mathrm{a}}-\mathrm{W}_{\text {seep }}-\right.$ $\left.\mathrm{Q}_{\mathrm{gw}}\right) \quad$ (Eq.1)

where $\mathrm{t}$ is the simulation period, SWt is the soil water content after the simulation period, SW0 is the soil water content at the beginning of the simulation period, and Rday, Qsurf, ETday, wday, and Qgw are daily values (in $\mathrm{mm}$ ) for precipitation, runoff, evapotranspiration, infiltration and return flow, respectively. In the second phase, it simulates the channel hydrology, where the loadings calculated earlier are routed through the stream network of the basin [10]. The Modified Universal Soil Loss Equation (Eq. 2) (MUSLE) [17] , has been used by Swat model. The difference compared to USLE is that the rainfall energy factor is replaced with a runoff factor.

Sed $=11.8(\mathrm{Q}$ surf $\times \mathrm{q}$ peak $\times$ area hru $) 0.56 \times$

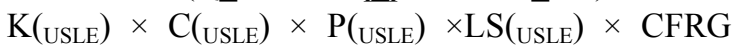
(Eq.2)

where Sed is the sediment yield on a given day (tons), Qsurf is the surface runoff volume ( $\mathrm{mm}$ $\mathrm{H} 2 \mathrm{O}) / \mathrm{ha})$, qpeak is the peak runoff rate $(\mathrm{m} 3 / \mathrm{s})$, area hru is the area of the HRU (ha), Kusle the USLE soil erodibility factor, Cusle the USLE cover and management factor, Pusle the USLE support practice factor, LSusle the USLE topographic factor and CFRG is the coarse fragment factor..

\subsubsection{SWAT-CUP}

SWAT-CUP (SWAT Calibration and Uncertainty Procedures) developed by Abbaspour [18], offers a range of more extensive and richer functions and interfaces for parameterization and calibration of the model. This tool integrates the algorithm SUFI2 , which is a method widely used for the calibration of the SWAT model at large scales. This stochastic method uses Latin Hypercube sampling to discretize the range of parameter variation and define their optimal values [6]. The operation of the SWAT-CUP tool is based on the use of the output files generated in the SWAT model execution step in ArcSWAT [6].

\subsubsection{DATAS NEEDS}

The GDEM-ASTER data (Global Digital Elevation Model from the ASTER sensor) has been used as the relief representation for this study, which is characterized by a spatial resolution of $30 \mathrm{~m} \times 30$ $\mathrm{m}$. It is widely used in hydrological modeling of watersheds [19]. Land use is one of the fundamental elements of hydrological modeling and plays a decisive role in the functioning of hydrological processes. In the SWAT model, land use and soil map were used for the division of the basin into elementary units, and also for the estimation of erosion rate, and surface flow. The acquisition of this information was made mainly from the data provided by the High Commission for Water and Forests and the fight against desertification (HCEFLD) and supplemented by the use of remote sensing space techniques.

\subsubsection{HYDRO-METEOROLOGICAL DATA}

The climate data collected for the implementation of the model include daily values of precipitation, minimum and maximum temperature, relative humidity, wind speed and solar radiation from 03 stations to the basin enclosure. Daily precipitation measurements and hydrometric measurements were required from a network of climatic stations of the Hydraulic Agency of Sebou Basin for the period (1/1/1979-12/07/2014), and completed by other data were also captured from the Texas A \& M Global Weather Database (http://globalweather.tamu.edu/) Re-analysis of the Academic Climate Prediction System (CFSR) to fill in the missing parts as recommended by Dile and Srinizan [20 - 21]. These data have been prepared for integration into the SWAT model (Fig. 2). The entire basin was discretized into HRUs. Since there are $30 \mathrm{~m}$ high spatial resolution maps, the generation of 
hydrological units produces small units that are of no interest in modeling but add to the rigging operation. To minimize these units having very small areas of a few pixels, a threshold of $10 \%$ was adopted for the three layers. After this refinement, the number of HRUs is finally fixed 587 HRUs.

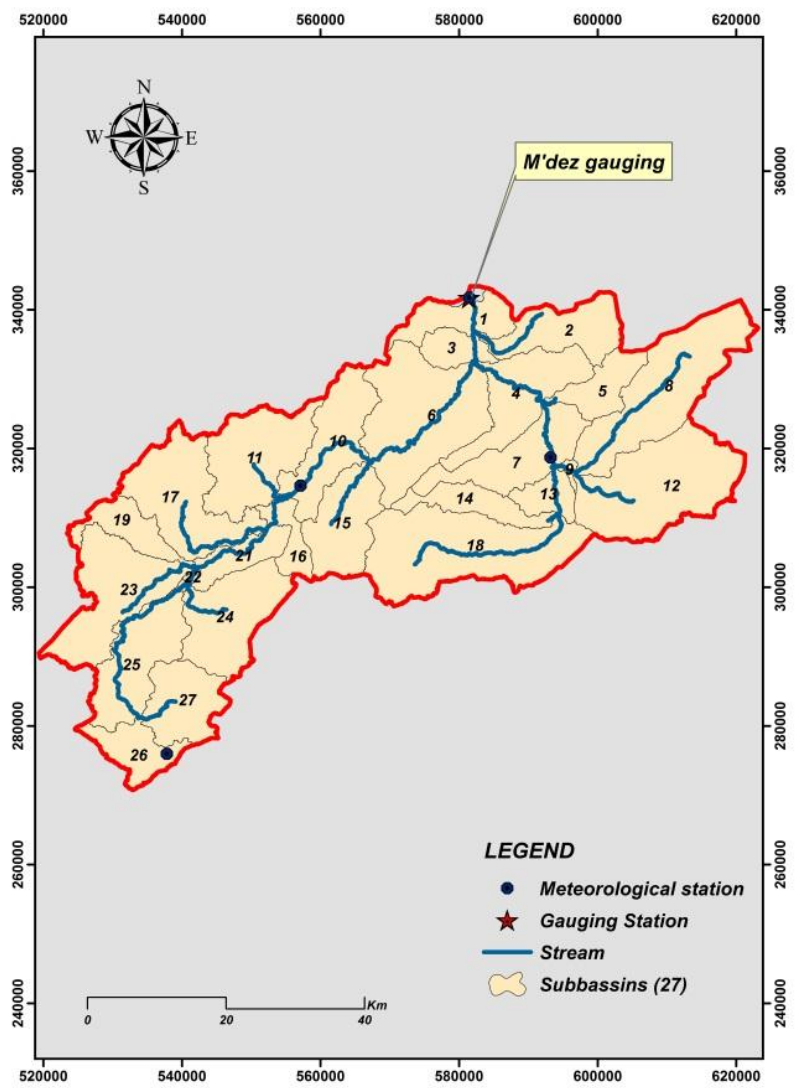

Fig. 2 : Delineation of sub-basins and gauging situation of the M'dez watershed

\subsubsection{SIMULATION CALIBRATION AND VALIDATION OF THE MODEL SWAT}

The simulation period is defined over 24 years and is subdivided into:

- Three years as a warm-up period (January 1990 to December 1992) recommended to optimize calibration, and this period aims to let the model do these first two complete hydrological cycles;

- Calibration period (Jan.1993 to Dec. 2002);

- Validation period (Jan.2003 to Dec. 2013);

\subsection{RUSLE METHODS}

The second method was used for assessing the potential erosion risk areas is the Universal Soil Loss Equation developed by Wischmeier and Smith [22]. RUSLE estimates the average annual soil loss in tons/yr.

$\mathrm{A}=\mathrm{R} \times \mathrm{K} \times \mathrm{LS} \times \mathrm{P} \times \mathrm{C}$

Where $A$ is the soil loss per unit of area ( $t /$ ha/year). The $\mathrm{R}$ factor is rainfall and runoff erosivity factor (MJ $\mathrm{mm} / \mathrm{ha} \mathrm{h}$ year). $\mathrm{K}(\mathrm{t} \mathrm{h} / \mathrm{MJ} \mathrm{mm})$ is soil erodibility factor, LS (unit-less) is a topographic factor, C (dimensionless) is a crop management factor, and $\mathrm{P}$ (dimensionless) is a conservation practice factor.

The USLE was improved, which led to the development of the revised universal equation of soil losses (RUSLE) which has the same equation as USLE but with several improvements to verify the factors. The manual of agriculture No. 703 [23] published by the United States department of agriculture (USDA) describes this method in every detail.

\subsubsection{RAINFALL EROSIVITY R- FACTOR}

The rainfall erosivity (the R-factor or EI30) (in Mj.mm/ha.h.an) in RUSLE model is defined as a long-term average of the product of the kinetic energy [24]. RUSLE quantifies the effect of raindrop impact and also reflects the amount and rate of runoff, likely to be associated with the rain [23]. [22] Noted that a period of 22 years of measurements is satisfactory to estimate the rainfall erosivity. The $\mathrm{R}$ factor is the index presented by Wischmeier and al [22] and is defined as the product of the kinetic energy of a storm and its maximum intensity during a $30 \mathrm{~min}$ interval (Eq. 4)

$\mathrm{EI} 30=(\mathrm{Ec}) \times(\mathrm{I} 30)$

Because of the limitations of the data (rain intensity and rain gauges registers) [25], the (Eq. 5) generated by Corte's [26], was selected and expressed as follows:

$\mathrm{Y}=2.8959 \mathrm{X}+0.002983 \mathrm{X}^{2}$

Where $\mathrm{Y}$ represents the annual index of rainfall erosivity in $\mathrm{mj} \mathrm{mm} / \mathrm{ha} \mathrm{h}$ year, and $\mathrm{X}$ is the annual average precipitation in $\mathrm{mm}$

This formula was applied to ten stations being in or near our study area for 24 years at a minimum of observation (91/92-16/17) collected from the hydraulic agency basin of Sebou [1] (Tab. 4). 


\subsubsection{SOIL ERODIBILITY K-FACTOR}

The K-factor is an empirical measure of soil erodibility as affected by intrinsic soil properties [27]. The $\mathrm{K}$-factor is related to soil texture, organic matter content, permeability class, and other factors, and it is mostly determined by the soil type [23]. $\mathrm{K}$ is the soil erodibility factor; it is the average soil loss in tons/hectare for a particular soil in cultivated, continuous fallow with an arbitrarily selected slope length of $22.13 \mathrm{~m}$ and slope steepness of $9 \%$. $\mathrm{K}$ is a measure of the susceptibility of soil particles to detachment and transport by rainfall and runoff. The texture is the principal factor affecting $\mathrm{K}$, but the structure, organic matter, and permeability also contribute [28]. The calculation of this factor is made as follows according to Wischmeier and Smith [22], equation (Eqs. 6-8) :

$\mathrm{K}=0.00021 \times \mathrm{M} 1.14 \times(12-\mathrm{OM})+3.25 \times$

$($ Csoilstr -2$)+2.5 \times($ Cperm -3$)$

Where $\mathrm{M}$ is the particle-size parameter

$M=($ Silt $\%+$ Sand $\%) \times(100-$ Clay\% $) \quad(E q .07)$

$\mathrm{OM}$ is the organic matter content

$\mathrm{OM}=1.72 \times \mathrm{OrgC}) \quad($ Eq.08)

Csoilstr is the structure of the soil and takes the values: $1=$ very fine granular, $2=$ fine granular, $3=$ medium or coarse granular and $4=$ blocky, platy or massive.

\subsubsection{TOPOGRAPHY LS-FACTOR}

The amount of erosion increases as the slope length increases [23]. LS-factor is estimated, starting from a DEM [29]. The LS factor was derived from the Stone and Hilborn [28], equation (Eq. 09) [30]. The calculation and spatialization factors L and S (Fig. 9), based on DEM data required several analysis. The LS factor equation.

$L S=\left(\left(" F l o w A c c_{-} \text {flow" } \times 30 / 22.1\right)^{\wedge} N N\right) \times$ $(0.065+0.045 \times$ "Slope" $+0.0065 " \times$ "Slope" $\times$ "Slope") (Eq.09)

Where $\mathrm{s}$ is the slope steepness in \%, slope length is the length of slope based on the DEM and NN is a value depended on the average slope (Tab. 1) [30].
Tab. 1: The values of NN based on the average slope

\begin{tabular}{|c|c|}
\hline Slope & NN \\
\hline$<1$ & 0.2 \\
\hline $1 \leq s<3$ & 0.3 \\
\hline $3 \leq s<5$ & 0.4 \\
\hline$>5$ & 0.5 \\
\hline
\end{tabular}

\subsubsection{CROP MANAGEMENT C FACTOR}

The $\mathrm{C}$ factor reflects the effects of the different land-uses in the rate of the erosion, and it is mainly related to the vegetation's cover percentage [31].

\subsubsection{SUPPORT PRACTICE $P$-FACTOR}

The $\mathrm{P}$ factor represents the mitigation effects of the different conservation practices like contouring, strip cropping and terraces [7]. The P-factor quantifies these practices by values which go from 1 for the soil where there are no conservation practices and of $1 / 10$ for a weak inclined soil where partitioned ridging is practised. The ploughing in level lines directs the roughness of the ground perpendicular to the slope of such kind to slow down the streaming. The $\mathrm{P}$ factor decreases up to 0.5 for slopes from 1 to $8 \%$. It increases gradually and tends towards 1 for slopes higher than $25 \%$. The ridging in level lines is twice more effective than the ploughing in level lines [32]. 


\section{RESULTS AND DISCUSSION \\ 4.1. IMPLEMENTATION OF THE MODEL SWAT MODEL}

The final land use map obtained (Fig. 3), with ten classes, it dominates respectively by pasture (40.64\%), forests 37.86\%) and agricultural land (17.55\%). According to the slope map (Fig. 4), our study area is characterized by a predominance of class slopes between $(5-25 \%)$ which extend over approximately $57.44 \%$ of the total area of the basin. In the center, in the part where the grades of the slopes are strong to an extreme, they extend on $32.48 \%$, located mainly in the center and the North-West, whereas the low slopes represent only $10.09 \%$ of the basin. Finally the soil map shows dominance of complex soils classes $(37.72 \%)$, followed by calcimagnetic soil $(35.72 \%)$, poorly developed soils $(18.57 \%)$, and $8 \%$ for other types of soils, (Fig. 5).

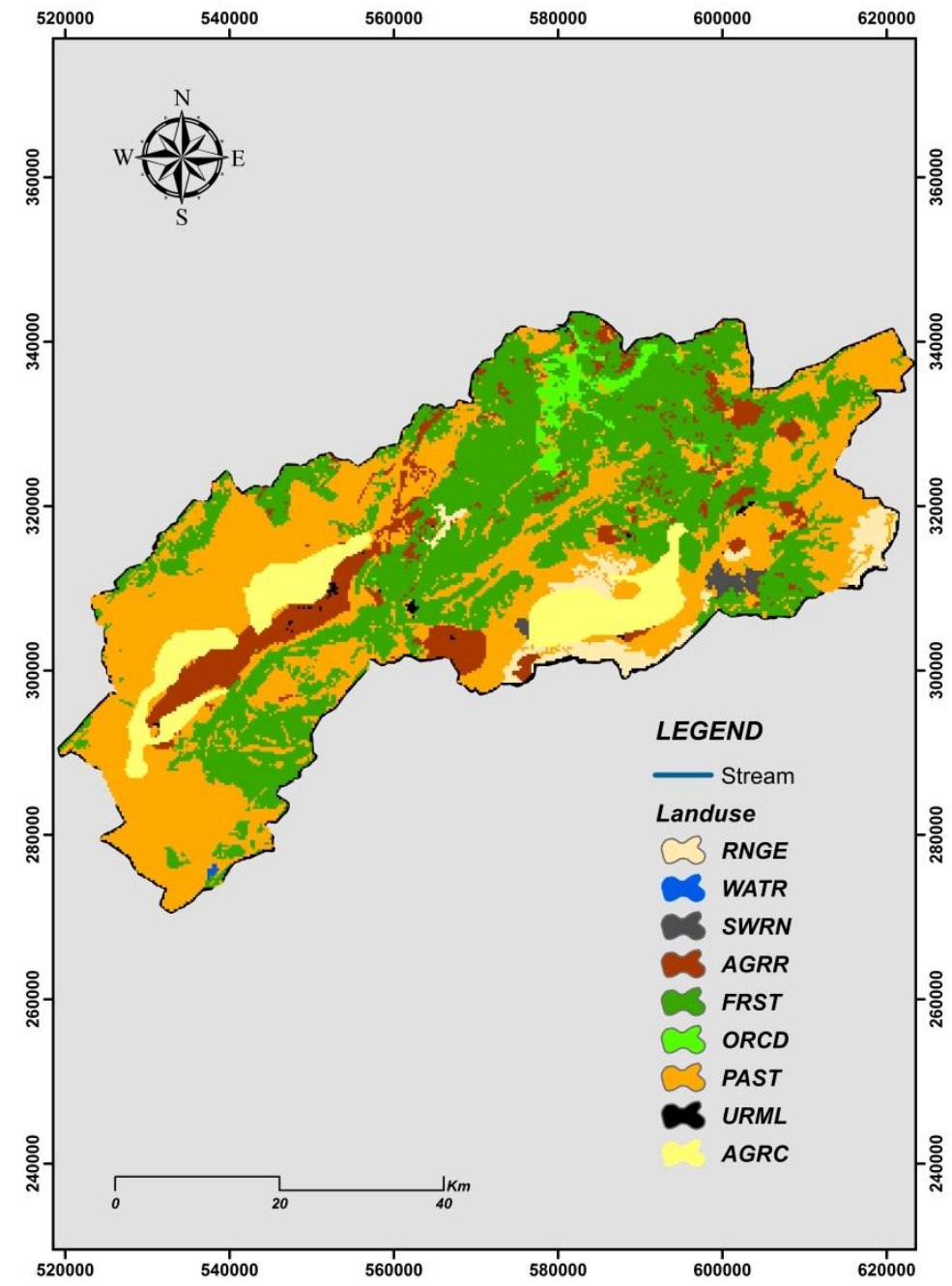

Fig. 3 : Land use map of the M'dez 

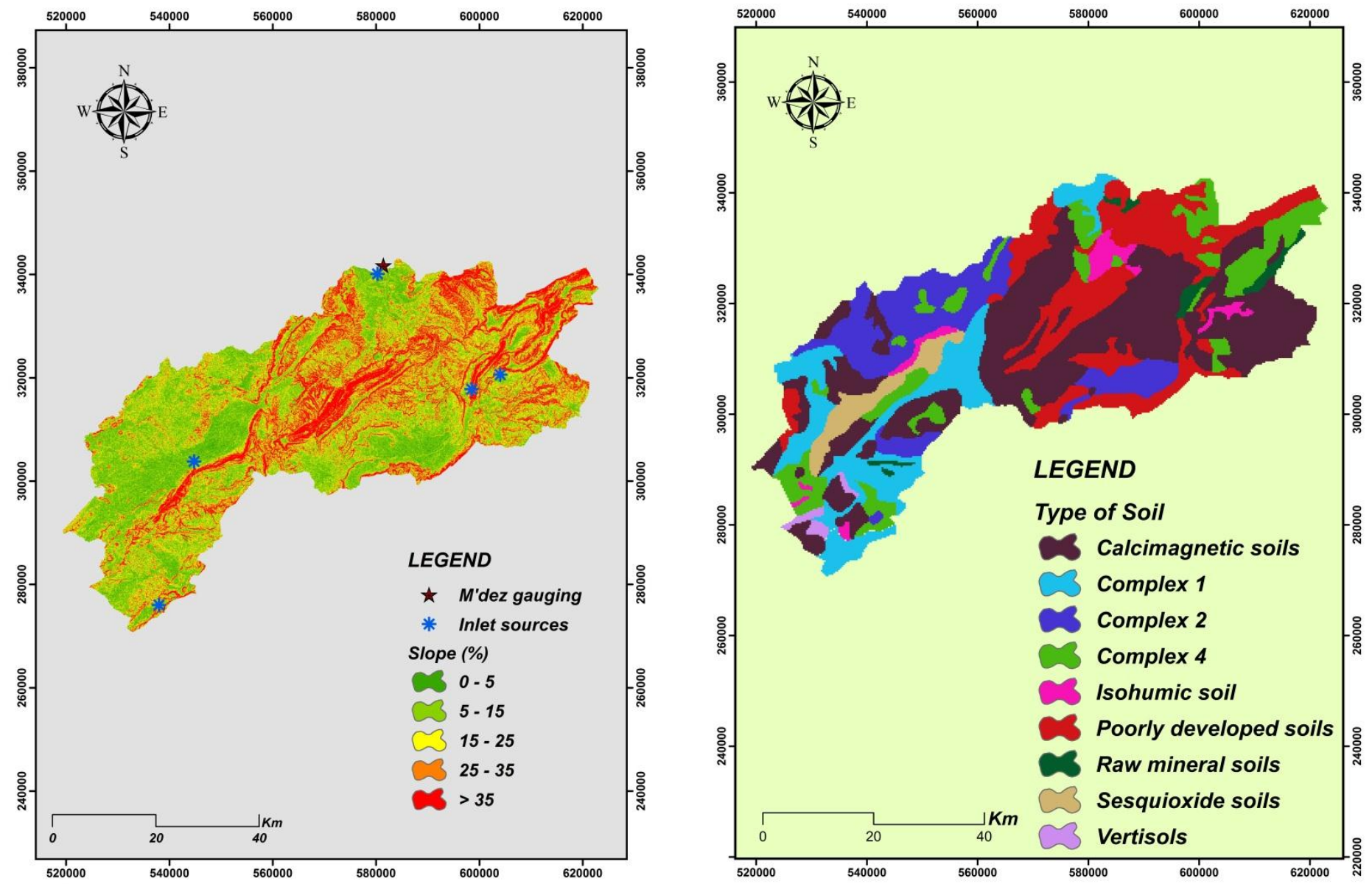

Fig. 4 : Slope map of the M'dez watershed

Fig. 5 : $\quad$ Soil map of the M'dez watershed 


\subsubsection{CALIBRATION AND VALIDATION OF THE SWAT MODEL}

It is necessary to identify key parameters and the parameter precision required for calibration [33]. In our study, Sol_BD, SMTMP, SOL_AWC, CN2, SNÖCOVER and SOL_ALB, are the six most sensitive parameters. The Nash and $\mathrm{R}^{2}$ determination coefficients obtained during this simulation are identical and are of the order of 0.65 , which indicates a satisfactory performance of the model at the calibration (1990-2002) phase according to the evaluation criteria of the model performance recommended for a monthly time step [34] (Tab. 2). For the validation period (2003-2013), the values of the performance coefficients decreased, remaining consistent with the recommended evaluation grid. This decline can be explained by the geological complexity of the basin which is characterized by its ability to infiltrate large volumes of water, while the base flow is provided by the sources, add on that, the operations of pumping for irrigation are difficult to estimate. The calibration is based on comparing the outputs simulated by the model with observation data. The evaluation and the adequacy between the two datasets (simulated and observed) is done through statistical indicators like the Nash-Sutcliffe measure of efficiency (NSE), the root-meansquare error observations SD ratio (RSR), which is derived from the root-mean-square error (RMSE), and the percent bias (PBIAS) described by the following equations (10), (11), (12).Tab.3 and (Fig. 6)

$$
\begin{aligned}
& \mathrm{NSE}=1-\frac{\sum_{\mathrm{i}=1}^{\mathrm{n}}\left(\mathrm{Q}_{\mathrm{obs}}^{\mathrm{i}}-\mathrm{Q}_{\text {sim }}^{\mathrm{i}}\right) 2}{\sum_{\mathrm{i}=1}^{\mathrm{n}}\left(\mathrm{Q}_{\mathrm{obs}}^{\mathrm{i}}-\mathrm{Q}_{\mathrm{obs}}^{\mathrm{mean}}\right) 2} \\
& \mathrm{RSR}=\frac{\sqrt{\sum_{\mathrm{i}=1}^{\mathrm{n}}\left(\mathrm{Q}_{\mathrm{obs}}^{\mathrm{i}}-\mathrm{Q}_{\text {sim }}^{\mathrm{i}}\right)^{2}}}{\sqrt{\sum_{\mathrm{i}=1}^{\mathrm{n}}\left(\mathrm{Q}_{\mathrm{obs}}^{\mathrm{i}}-\mathrm{Q}_{\text {mean }}\right) 2}} \\
& \mathrm{PBIAS}=\left[\frac{\sum_{\mathrm{i}=1}^{\mathrm{n}}\left(\mathrm{Q}_{\mathrm{obs}}^{\mathrm{i}}-\mathrm{Q}_{\text {sim }}^{\mathrm{i}}\right) * 100}{\sum_{\mathrm{i}=1}^{\mathrm{n}}\left(\mathrm{Q}_{\mathrm{obs}}^{\mathrm{i}}\right)}\right]
\end{aligned}
$$

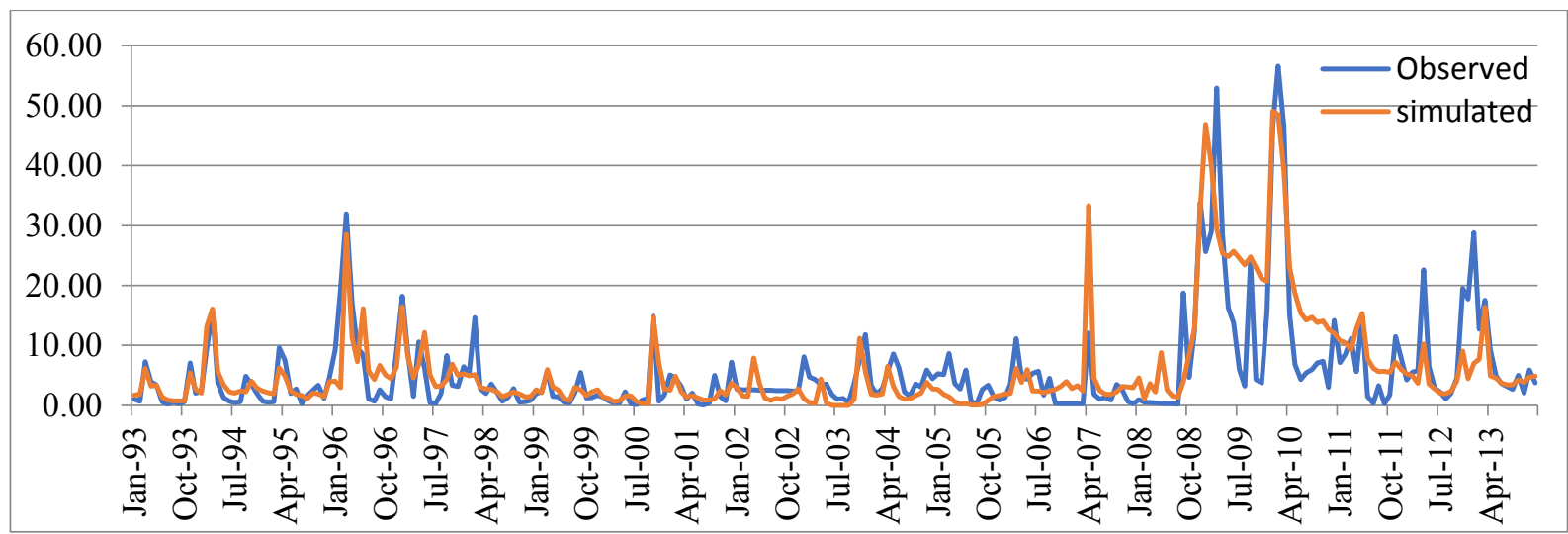

Fig. 6 : $\quad$ Correlation between observed and simulated flow during calibration (1993-2013)

Tab. 2 : Monthly performance evaluation grid (Moriasi et al. 2007)

\begin{tabular}{|l|l|c|c|}
\hline Performance Rating & RSR & NSE & PBIAS (\%) \\
\hline Very good & $0.00<\mathrm{RSR}<0.50$ & $0.75<\mathrm{NSE}<1.00$ & PBIAS $< \pm 10$ \\
\hline Good & $0.50<\mathrm{RSR}<0.60$ & $0.65<\mathrm{NSE}<0.75$ & $\pm 10<$ PBIAS $< \pm 15$ \\
\hline Satisfactory & $0.60<\mathrm{RSR}<0.70$ & $0.50<\mathrm{NSE}<0.65$ & $\pm 15<$ PBIAS $< \pm 25$ \\
\hline Unsatisfactory & RSR $>0.70$ & NSE $<0.50$ & PBIAS $> \pm 25$ \\
\hline
\end{tabular}


Tab. 3 : Summary of model performance for calibration and validation periods

\begin{tabular}{|c|c|c|c|c|c|}
\hline \multirow{2}{*}{ Years } & \multirow{2}{*}{ Periods } & \multicolumn{4}{|c|}{ Evaluation of statistics of parameters } \\
\cline { 3 - 6 } & & $\mathrm{R}^{2}$ & NSE & RSR & Pbias \\
\hline $93-02$ & Cal & 0.65 & 0.65 & 0.59 & -2.4 \\
\hline $03-13$ & Val & 0.61 & 0.56 & 0.66 & -8.99 \\
\hline $93-13$ & All periods & 0.59 & 0.64 & 0.63 & -6.96 \\
\hline
\end{tabular}

\subsection{IMPLEMENTATION OF THE RUSEL METHOD}

\subsubsection{R-FACTOR}

The erosivity map (Fig. 7) is obtained from the Geostatistical analysis tool of Arcgis 10.2. The most important values are those of DAR ELHAMRA station (1985.90 Mj.mm/ha.h.yr) and AGUELMANE SIDI ALI station (1787.16 Mj.mm/ha.h.yr) located respectively to the North East and South West of the basin. The lowest value is shown at the north and south centre of the basin

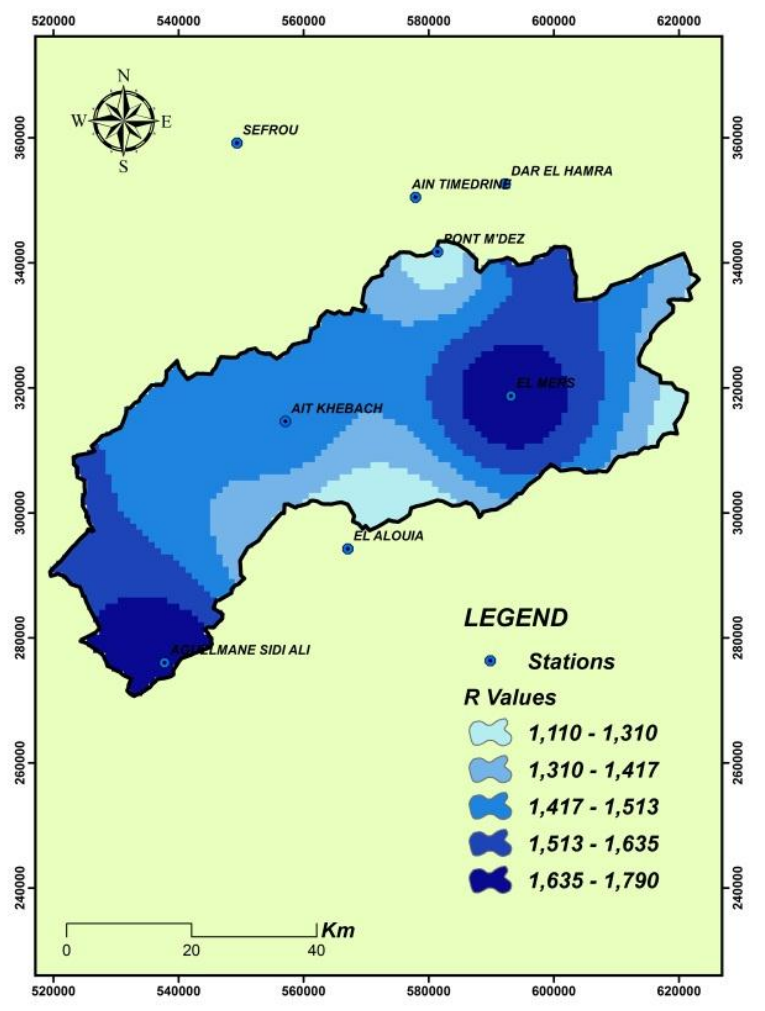

Fig. 7 : Erosivity map of the M'dez watershed

\subsubsection{K-FACTOR}

The K-factor map of our study area is based on data provided by the HCEFLCD and [35], they show that $0.3 \%$ of the M'dez watershed soils are very little erodible, $19,71 \%$ are of low to medium erodibility, while highly to highly erodible soils account for about $79.99 \%$ of the total area of the island. watershed. (Fig 8).

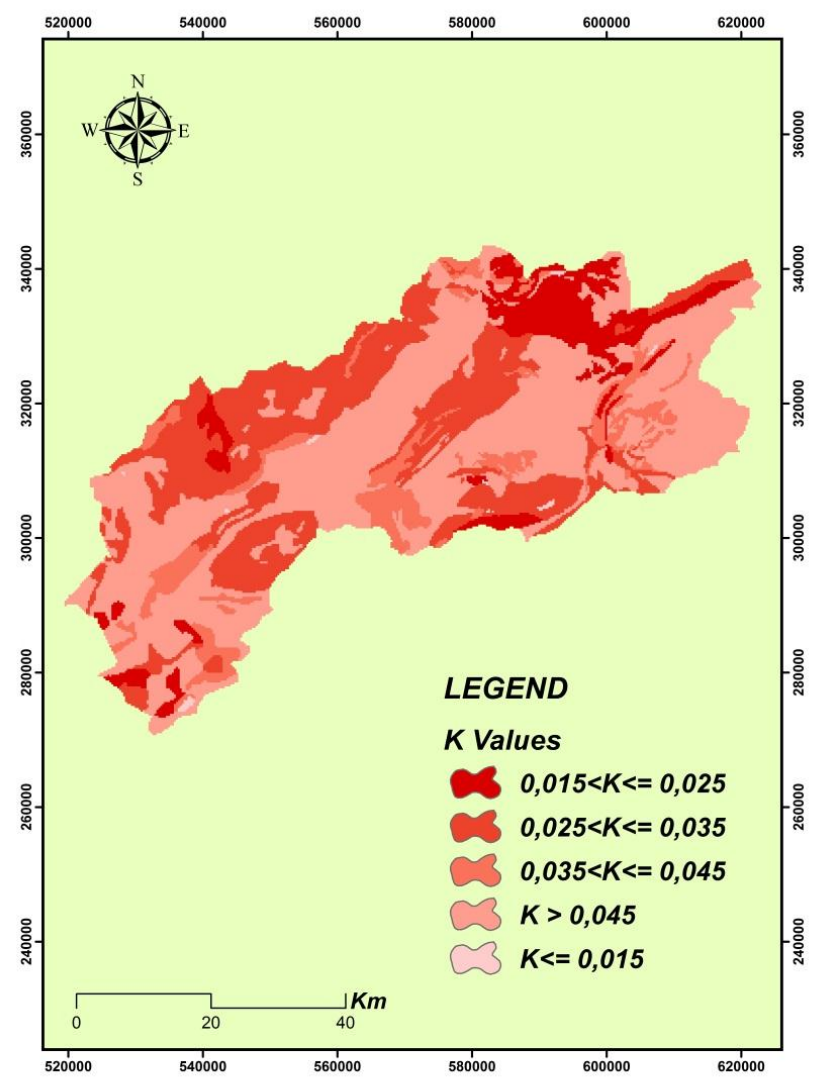

Fig. 8 : K map of M'dez watershed 


\subsubsection{LS-FACTOR}

The LS map of our study area show that most of the basin presents value between 0 and 4.65. (Fig. 9)

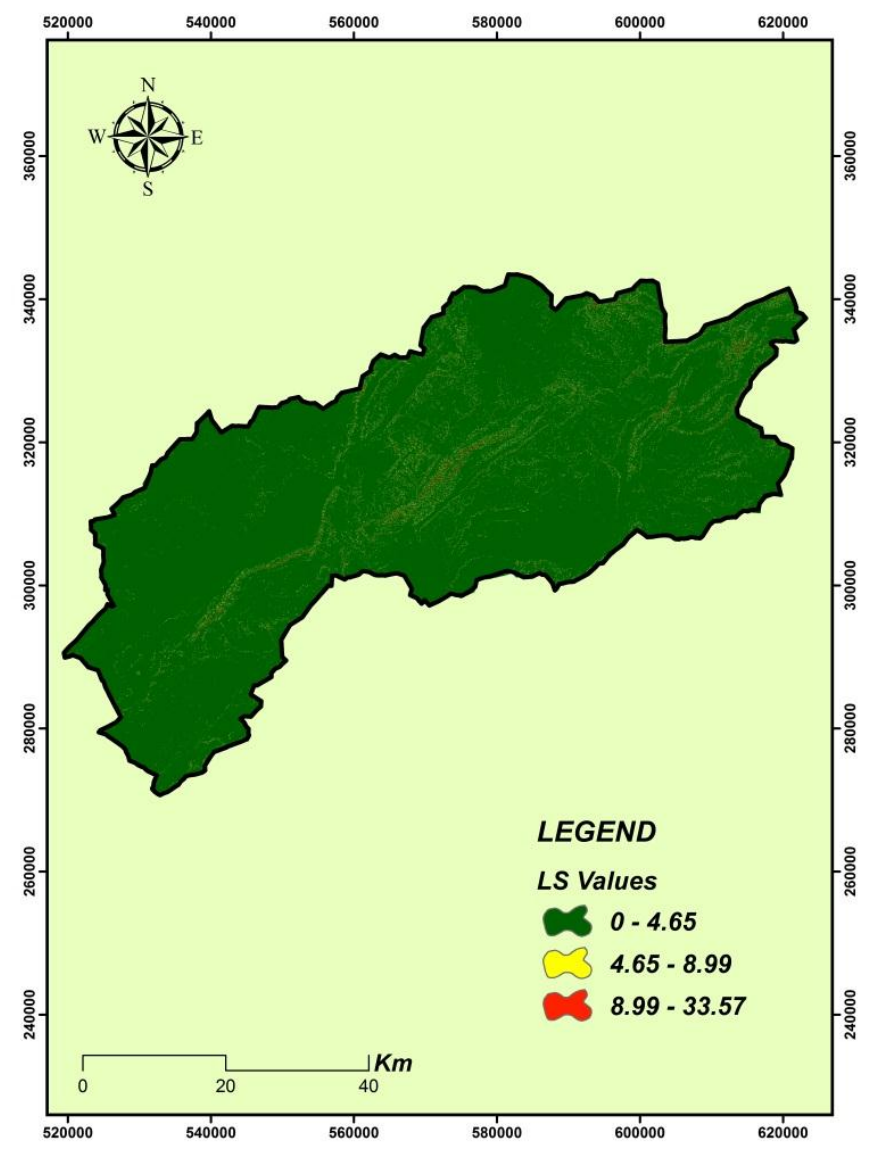

Fig. 9 : LS factor map of M'dez watershed

\subsubsection{C-FACTOR}

In our case, the selected values of factor $\mathrm{C}$ were obtained based on the studies of several researchers, as well as the tables published in the manual for Erosion and Sediment Control in Georgia Soil Water and Conservation Commission [36]. Subsequently integrated into the land use map was provided by the Office of the High Commissioner for Water and Forests and Desertification (HCEFLD), and supplemented by he use of remote sensing space techniques. (Tab. 4; Fig. 10)
Tab. 4 : The values of c factor

\begin{tabular}{|c|c|c|c|}
\hline Swat Code & Landuse & Factor-C & Authors \\
\hline WATR & Water & 0 & {$[36]$} \\
\hline FRST & Mixed Forest & 0.08 & \multirow{3}{*}[36]{} \\
\hline$O R C D$ & Orchards/Vineyard & 0.28 & \\
\hline$A G R C$ & Small Grains & 0.26 & \\
\hline$R N G E$ & Grasslands/Herbaceous & 0.32 & {$[38]$} \\
\hline SWRN & South Western Range & 1 & \multirow{2}{*}[31]{} \\
\hline$P A S T$ & Pasture & 0.08 & \\
\hline$A G R R$ & $\begin{array}{c}\text { Agricultural land row } \\
\text { crops }\end{array}$ & 0.6 & {$[39]$} \\
\hline
\end{tabular}

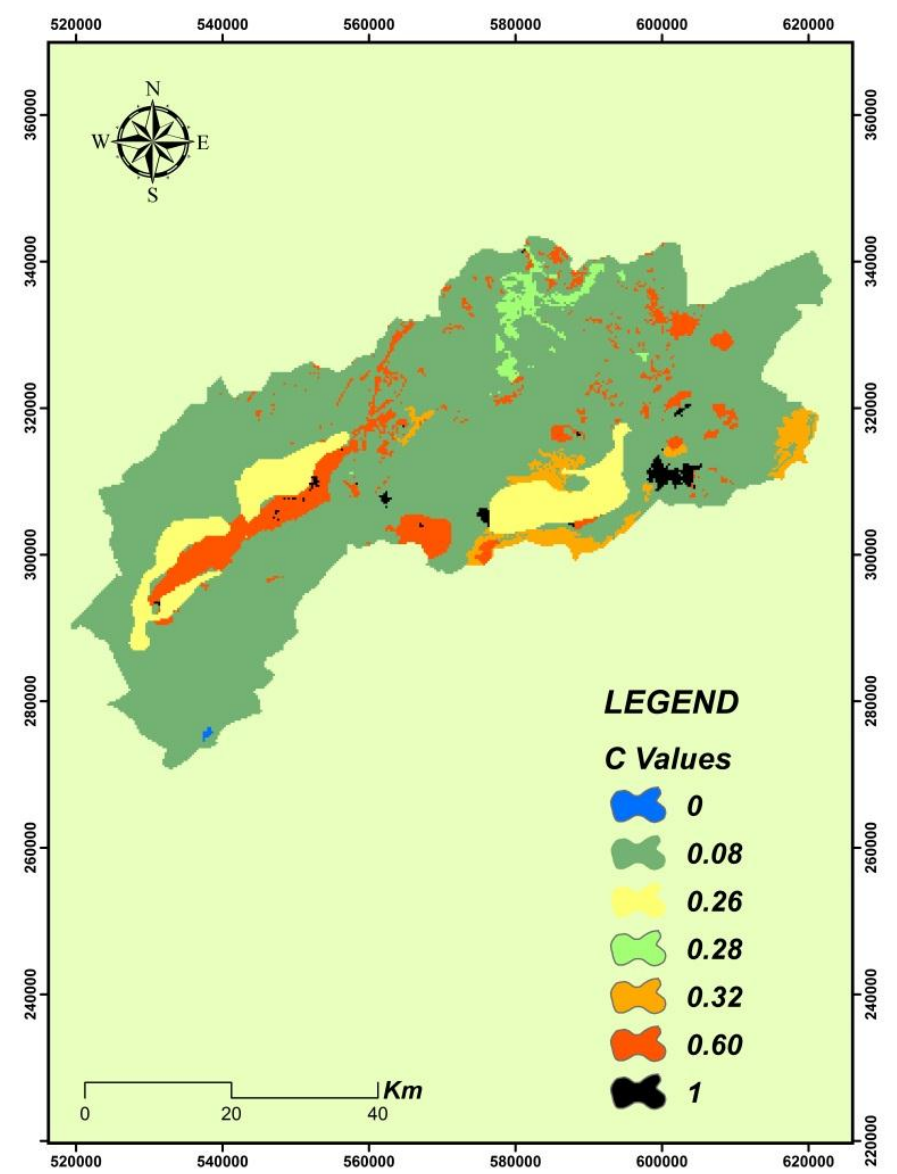

Fig. 10 : $\quad$ C factor map of M'dez watershed 


\subsubsection{P-FACTOR}

For our study area, we use the table (Tab. 5) published in the manual for Erosion and Sediment Control in Georgia USA (Georgia Soil Water and Conservation Commission [36], in order to generate the $\mathrm{P}$ factor map (Fig. 11)

Tab. 5 : The value of P-Factor

\begin{tabular}{|c|c|}
\hline Landuse & P-Factor \\
\hline FRST & 0.5 \\
\hline AGRR & 0.5 \\
\hline RNGE & 1 \\
\hline WATR & 1 \\
\hline SWRN & 1 \\
\hline ORCD & 1 \\
\hline PAST & 1 \\
\hline AGRC & 1 \\
\hline
\end{tabular}

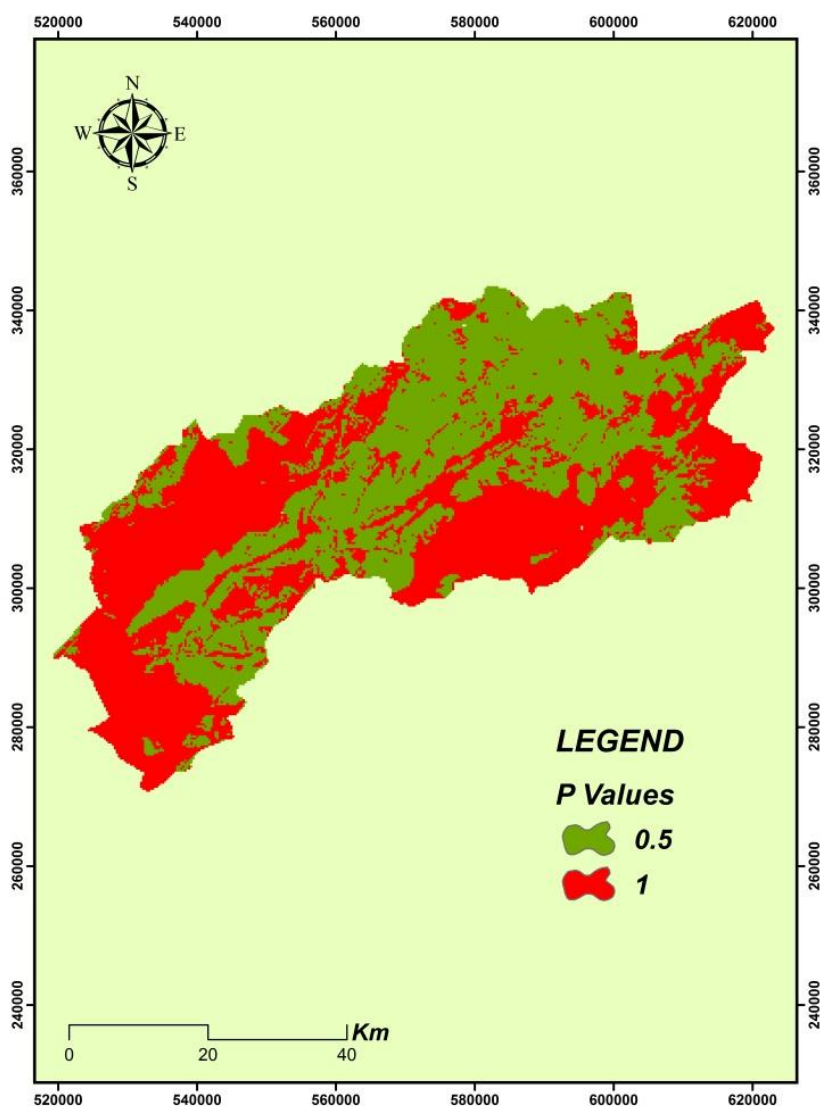

Fig. 11 : $\quad$ P factor map of $M^{\prime}$ dez

\subsection{Erosion report}

The results obtained with the application of the RUSLE equation show that $98.66 \%$ of the basin area is exposed to a low to very low erosion risk $(<7 \mathrm{t} / \mathrm{ha} /$ year) and $1.34 \%$ basin is at moderate risk. The most affected areas are in the eastern center of the basin, with average slopes greater than $30 \%$ (Fig. 12). The soil erosion map obtained by the hydro-agricultural model (SWAT) also shows that $84.47 \%$ of the surface area of the M'dez basin is exposed to a low to very low risk of erosion $(<7$ $\mathrm{t} / \mathrm{h} /$ year) and $15.52 \%$ basin is at moderate risk. The most affected areas are located in the east of the basin (Fig. 13). Generally, both models have shown that the risk of erosion in the M'dez basin is considered low to moderate. However, the spatial distribution of erosion values can be explained by the mode of operation of the two models. The USLE method, is based on kinetic energy in the delivery of potential erosion quantities, in a terrestrial phase, on the other hand the Swat model, works in two phases, the terrestrial first which consist to quantify the quantities of the sediment to be delivered at the level of each sub-basin discretized in several hydrological units, and the second fluvial phase, which makes it possible to evaluate the quantities of the transported sediments. In our case, the transport rate of these sediments is reduced because of the porous nature of the M'dez basin soil, which consequently minimizes the amount of erosion delivered by each sub-basins. As a result, several researchers [2-9-40], confirmed the same values found by SWAT model respectively (6.22 t/h/year; $1.75 \mathrm{t} / \mathrm{h} /$ year; $1.95 \mathrm{t} / \mathrm{h} /$ year). This low erosion rate, which dominates most of the basin, is due to several factors, the most important of which is the permeability of the highly fissured geological formation that characterizes the M'dez basin, such as calcarodolomitic rocks, without forgetting vegetal cover dominated by green oak forest. 


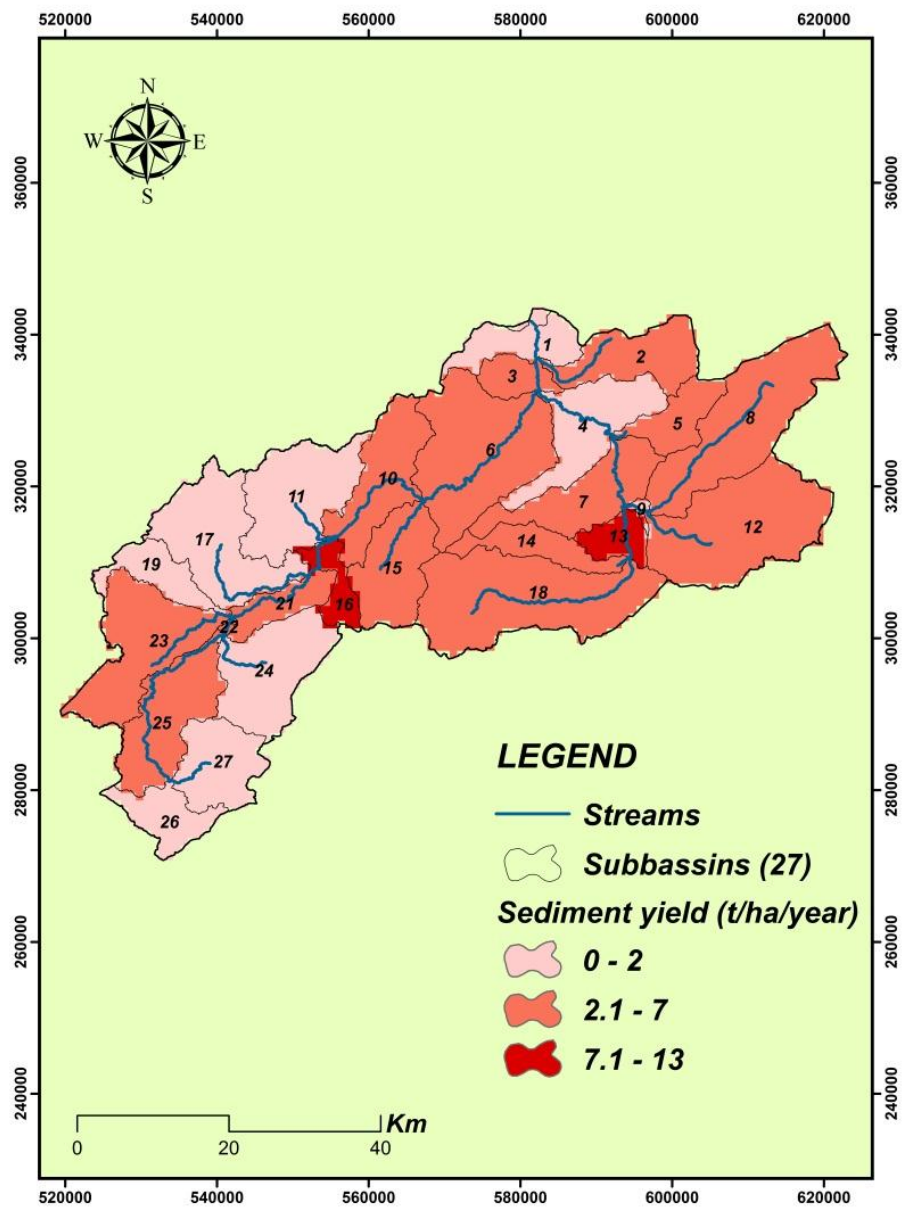

Fig. 12 : The soil erosion risk map of M'dez watershed based on the implementation of RUSEL equation

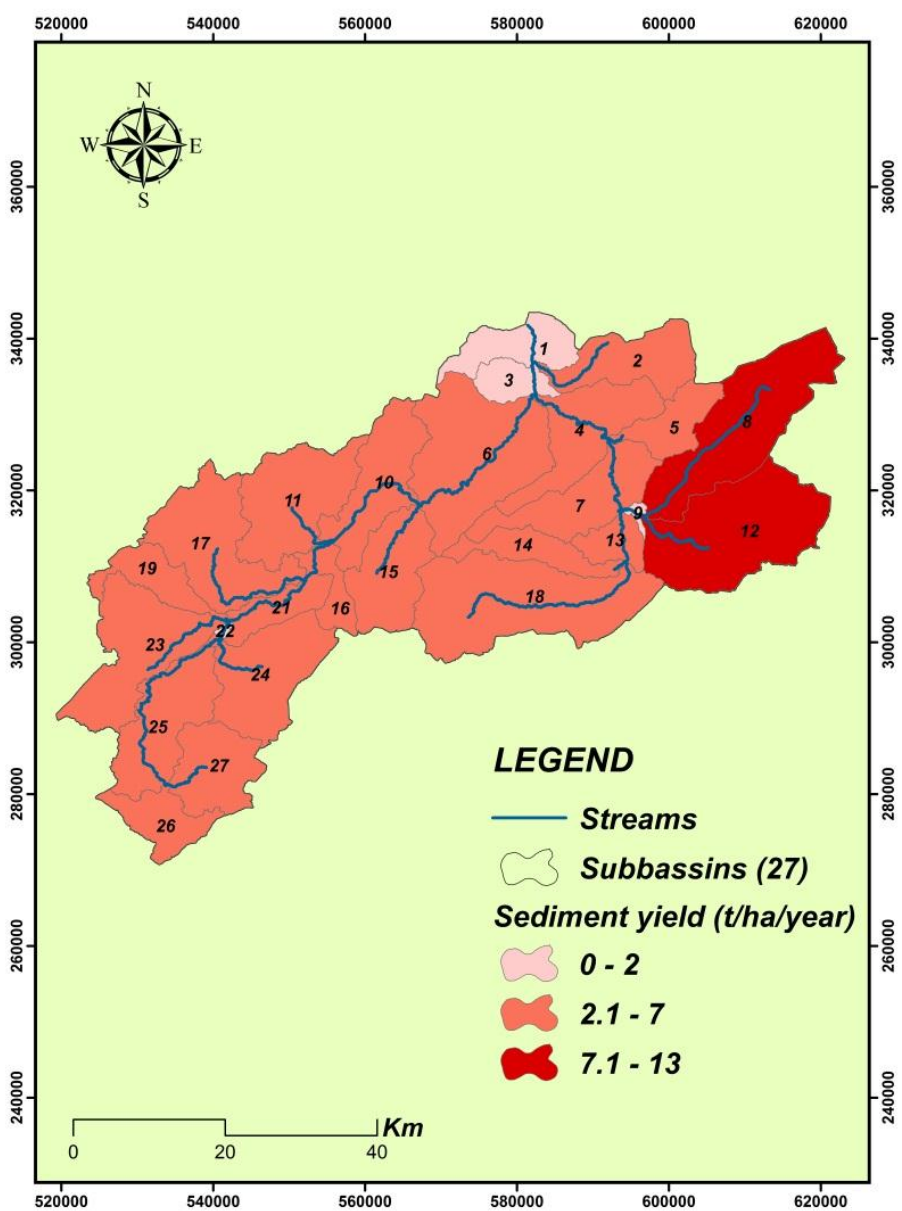

Fig. 13 : The soil erosion risk map of M'dez watershed based on the SWAT model (MUSLE) 


\section{CONCLUSIONS}

The soil erosion risk assessment of the M'dez basin was carried out by two methods: the RUSLE method and the SWAT hydro-agricultural model. The results obtained during this work led to the production of two erosion maps for the basin in study area. Comparison of the two methods showed that a large area of the basin is exposed to a low to moderate risk of erosion; with about $98.66 \%$ of the basin area by the RUSLE empirical model, and $84.47 \%$ by the Swat model. Indeed, these two methods have given very interesting results in terms of a quantitative description of the M'dez basin. Thus, the established maps allowed a classification to quantify the losses in soils and its spatial distribution. However, the Swat model is an interesting and complete approach. It takes into consideration transport and sedimentation and thus quantifies sediment production and nutrients at the watershed level. Currently, it is recommended to use the performance of the Swat model in sustainable environmental and agricultural policies to assess sedimentation and pollution generated by agricultural activities and transport downstream.

\section{REFERENCES}

1. ABHS, Study to update the management master plan integrates water resources in the Sebou watershed. Sebou-mission review, Kingdom of Morocco Sebou Hydraulic Basin Agency, (2005)

2. Boufala M. El Hmaidi A. Chadli K. et al, Hydrological modeling of water and soil resources in the basin upstream of the Allal El Fassi dam (Upper Sebou watershed, Morocco). Model. Earth Syst. Environ,(2019).

https://doi.org/10.1007/s40808-01900621-y

3. FAO, Global soil status, processes and trends. Status of the World's Soil Resources (SWSR) Main Report of the Food and Agriculture Organization, New York, United Nations, (2015)

4. Toumi S, Application des techniques nucléaires et de la télédétection a l'étude de l'érosion hydrique dans le bassin versant de l'Oued Mina. Thèse de
Doctorat Es-Sciences, L'école nationale supérieure d'hydraulique, Algérie, 175 p, ,(2013)

5. Knapp B. van Dommelen P, The Mediterranean. In Archaeology Vol II. Encyclopedia of Life Support Systems, (2005)

6. Abbaspour KC, User manual for SWATCUP, SWAT calibration and uncertainty analysus programs. Swiss Federal Institute of Aquatic Science and Technology, Eawag, Duebendorf, Switzerland. 103 pp, (2011)

7. Gitas I. Z, Douros K., Minakou C., Silleos G.N. and Karydas C.G., Multi-temporal soil erosion risk assessment in $\mathrm{N}$. Chalkidiki using a modified USLE raster model. EARSel eProceedings8, (2009)

8. Panagopoulos Y. Makropoulos C. and Mimikou M, Decision Support for Agricultural Water Management. Global Nest Journal, Special Issue on Water Resources, Hydrology and Hydraulics, Vol. 14(3), pp. 255-263, (2012)

9. Hazan R. et Lazarevic D, Hydrologie en zone karstique au Maroc : Sebou - Beth. Pub. Annuaires Hydrol. Maroc 1962-1963 et Actes Coll. hydrol. roches fissurées. Dubrovnik 1965. publi. 1967. Ass. Int. Hydrol. Sci, UNESCO Paris 1967, pp 275292, (1965)

10. Neitsch SL. Arnold JG. Kiniry JR. Williams JR. and King K.W, Soil and Water Assessment Tool -Theoretical Documentation - Version 2009.Grassland, Soil and Water Research Laboratory, Agricultural Research Service and Blackland Research Center, Texas Agricultural Experiment Station, Temple, Texas, (2011)

11. Arnold JG. Kiniry JR. Srinivasan R. Williams JR. Haney EB and Neitsch SL, Soil and Water Assessment Tool, Input/Output File Documentation,Version 2012. Texas Water Research Institute. Technical Report 439, College Station, Texas, (2012)

12. Di Luzio M. Srinivasan R. Arnold JG. Neitsch SL, Soil and Water Assessment Tool. ArcView GIS Interface Manual: Version 2000. GSWRL Report 02-03, BRC Report 02-07. Published by Texas Water Resources Institute TR-193, College Station, TX. 346p, (2002)

13. Baker TJ. Miller SN, Using the soil and water assessment tool (SWAT) to assess

Corresponding author: simoboufala@gmail.com 
land use impact on water resources in an East African watershed. J Hydrol 486:100-111, (2013)

14. Setegn GS. Srinivasan R. Dargahi B, Hydrological modelling in the Lake Tana Basin, Ethiopia using SWAT model. Open Hydrol J 2(1), (2008)

15. Borah DK. Bera M, Watershed-scale hydrologic and nonpoint source pollution models: Review of mathematical bases. Trans ASAE 46(6):1553, (2003)

16. Kiros et al, Performance Evaluation of SWAT Model for Land Use and Land Cover Changes in Semi-Arid Climatic Conditions: A Review. Hydrol Current Res, 6:3 DOI: 10.4172/21577587.1000216, (2015)

17. Williams JR, Chapter 25. The EPIC Model. In: Computer models of watershed hydrology. Water Resources Publications. Highlands Ranch. pp 909-1000,(1995)

18. Abbaspour K. Yang J. Maximov I. Siber R. Bogner K. Mieleitner J. Zobrist J. Srinivasan R, Modeling hydrology and water quality in the pre-alpine/alpine Thur watershed using SWAT. J Hydrol 333:413-430, (2007)

19. Hirt C. Filmer MS. Featherstone WE, Comparison and validation of recent freely available ASTER-GDEM ver1, STRM ver4.1 and GEODATA DEM-9S ver3 digital elevation models over Australia, Australian Journal of Earth Sciences 57 (3), pp. 337-347, (2010)

20. Dile YT. Srinivasan R, Evaluation of CFSR climate data for hydrologic prediction in data-scarce watersheds: an application in the Blue Nile River Basin. J Am Water Resour Assoc 50(5):12261241, (2014)

21. Fuka DR. Walter MT. MacAlister C. Degaetano AT. Steenhuis TS. Easton ZM, Using the climate forecast system reanalysis as weather input data for watershed models. Hydrol Process 28(22):5613-5623, (2013)

22. Wischmeier WH. Smith DD, Predicting rainfall erosion losses - a guide for conservation planning. U.S. Department of Agriculture, Agriculture. Handbook 537, (1978)

23. Renard KG. Foster GR. Weesies GA. McCool DK. Yoder DC, Predicting soil erosion by water - a guide toconservation planning with the Revised Universal Soil Loss Equation (RUSLE). United States
Department of Agriculture, Agricultural Research Service (USDA-ARS) Handbook No. 703. United States Government Printing Office, Washington, DC, (1997)

24. Benchettouh A, Spatial estimation of soil erosion risk using RUSLE/GIS techniques and practices conservation suggested for reducing soil erosion in Wadi Mina watershed (northwest, Algeria) Arab J Geosci (2017) 10:79 - DOI 10.1007/s12517-017-2875-6, (2012)

25. Chadli K, Estimation of soil loss using RUSLE model for Sebou watershed (Morocco) Model. Earth Syst. Environ. (2016) 2:51 DOI $10.1007 / \mathrm{s} 40808-016-$ 0105-y, (2016)

26. Corte's THG, Caracterizacion de la erosividad de la lluvia en México utilizando meétodos multivariados. Tesis M. C. Colegio de postgraduados, Montecillos, México, (1991)

27. Fu BJ. Zhao WW. Chen LD. Zhang QJ. Lu YH. Gulinck H. Poesen J, Assessment of soil erosion at large watershed scale using RUSLE and GIS: a case study in the loess plateau of China. Land Degrad Dev $16: 73-85,(2005)$

28. Stone RP. Hilborn D, Universal soil loss equation (USLE) factsheet. Ministry of Agriculture, Food and Rural Affairs, Ontario, (2012)

29. Wang G. Wente S. Gertner GZ. Anderson A, Improvement in mapping vegetation cover factor for the universal soil loss equation by geostatistical methods with Landsat thematic mapper images. Int $\mathrm{J}$ Remote Sens 23(18):3649-3667, (2002)

30. Sinha K.C. Labi S, Transportation Decision Making: Principles of Project Evaluation and Programming, In: Chapter 13, Impacts on water resources Wiley Publications, (2007)

31. Jones DS. Kowalski DG and Shaw R.B, Calculating Revised Universal Soil Loss Equation (RUSLE) Estimates on Department of Defense Lands: A Review of RUSLE Factors and U.S. Army Land Condition-Trend Analysis (LCTA) Data Gaps. Center for Ecological Management of Military Lands, Department of Forest Science, Colorado State University, USA, (1996)

32. Sadiki A. Bouhlassa S. Auajjar J. Faleh A. Macaire JJ, Utilisation d'un SIG pour l'évaluation et la cartographie des risques d'érosion par l'Equation universelle des 
pertes en sol dans le Rif oriental (Maroc) : cas du bassin versant de l'oued Boussouab. Bulletin de l'Institut Scientifique, Rabat, section Sciences de la Terre, 2004, n²6, p. 69-79, (2004)

33. Andrade MA and al, Méthode basée sur l'homologie pour l'identification de répétitions de protéines en utilisant des estimations de signification statistique. J Mol Biol 298 (3): 521-37, (2000)

34. Moriasi DN. Arnold JG. Van Liew MW. Bingner RL. Harmel RD. Veith TL, Model evaluation guidelines for systematic quantification of accuracy in watershed simulations, Trans. ASABE, 50(3), 885900, (2007)

35. EZ-ZAHAOUANI B, Apports du modèle MUSLE et des techniques radiométriques à l'évaluation de l'impact du projet d'aménagement du bassin versant de l'Oued Sebou sur l'envasement du barrage Allal El Fassi, Projet de Fin d'Etudes présenté pour l'obtention du diplôme d'Ingénieur en Agronomie, Institut Agronomique et Vétérinaire HASSAN II , (2015)

36. Georgia Soil Water and Conservation Commission, Manuel for Erosion and Sediment Control in Georgia, (2000)

37. El Garouani A. Chen H. Lewis L. Tribak A et Abahrour M, Apport de la télédétection et du SIG pour le suivi spatio-temporel de l'occupation du sol et de l'érosion nette dans le bassin versant de l'Oued Tlata (Maroc). Actes de JSIRAUF, Hanoi, 1-9, (2007)

38. Ibrahimi S, Application du 210Pbexe comme une alternative à l'utilisation du $137 \mathrm{Cs}$ pour l'étude de la redistribution du sol sur des transects cultivés et non cultivés. Bassin versants El Hachef et Raouz, nord du Maroc, Thèse présentée pour l'obtention du doctorat en Sciences, Université Abdelmalek Essaadi, Tanger, Maroc, (2005)

39. Aït Brahim L. Sossey Alaoui F. Siteril H et Tahiri M, Quantification des pertes en sols dans le bassin versant Nakhla (Rif septentrional) ». Sciences et changements planétaires/séchresse.Volume 14, Numéro 2, 101-6, Note de recherche, (2003)

40. Karrat L. Elouadeihe K. Brehert JG. Hessane MA, Erosion et matières transportées en suspension dans le bassin versant de l'Oued Sebou en amont du barrage Allal Fassi (Moyen Atlas, Maroc),
Revue Marocaine de Géomorphologie, Numéro 1, pp 47-61, (2016).

"Corresponding author: simoboufala@gmail.com 